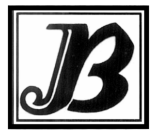

J. bio-sci. 22: 53-58, 2014

ISSN 1023-8654

http://www.banglajol.info/index.php/JBS/index

\title{
IN VITRO REGENERATION OF INDIGOFERA VISCOSA LAM.
}

\author{
E Rajabudeen ${ }^{1}$, A Saravana Ganthi ${ }^{*}$ Sivasubramanian S33, M Padma Sorna Subramanian ${ }^{4}$ \\ ${ }^{1}$ Dr. Zahir Husain College, Ilayankudi, Tamil Nadu, India \\ 2 Rani Anna Govt. College for Women, Tirunelveli, Tamil Nadu, India \\ 3jJ College of Arts and Science, Pudukottai, Tamil Nadu, India \\ 4Siddha Medicinal Plants Garden, CCRS, Mettur Dam, Tamil Nadu, India
}

\begin{abstract}
Context: In vitro propagation or tissue culture of plants offers a rapid means of producing large quality of clonal planting stock and propagation that are difficult to establish conventionally. Biotechnological tools are important for multiplication and genetic enhancement of the plants by adopting techniques such as in vitro regeneration and genetic transformations.

Objective: Effect of different plant growth regulators (PGRs) and their concentration on multiple shoot regeneration and callus formation was studied in Indigofera viscosa.

Materials and Methods: In vitro plant regeneration was achieved in nodal and shoot tip explants. The explants were cultured on MS medium supplemented with BAP and NAA.

Results: The nodal explants exhibited a greater number of healthy multiple shoots. The maximum callus induction was observed on MS medium supplemented with $1.5 \mathrm{mg} \mathrm{L}^{-1}$ 2,4-D. NAA and BAP combination proved to be the most effective treatment for promoting shoot multiplication. IBA was found to be the best rooting hormone than IAA or NAA. The plantlets showed high survival rate in the soil.

Conclusion: The present investigation clearly established and demonstrated the method of obtaining the new plantlets in Indigofera viscosa supported by different hormone concentrations
\end{abstract}

Key words: Callus, In vitro, Indigofera viscosa, nodal and shoot tip explants.

\section{Introduction}

Medicinal compounds from plants represent one of the largest and most diverse groups of plant secondary metabolites. In vitro propagation of medicinal plants with enriched bioactive principles and cell culture methodologies for selective metabolite production is found to be highly useful for commercial production of medicinally important compounds. Tissue culture protocols have been developed for several plants but there are many other species, which are over exploited in pharmaceutical industries and need conservation. It is now quite apparent that India has made big strides in the realm of biotechnology. The galloping rate, at which this advancement is continuing, holds out great promise for a better future.

The Fabaceae family (=Leguminosae) consists of approximately 650 genera and 18,000 species; it is one of the largest Angiosperm families (Polhill et al. 1981, Judd et al. 1999). Many plants of this family have been used in traditional systems of medicine. Still, several potent plants of Fabaceae are unexplored which deserve attention and research. Indigofera viscosa Lam. is such plant which has not been explored extensively by the scientific world so far. The genus Indigofera comprises around 700 species that are distributed geographically in tropical regions (Bakasso et al. 2008). Indigofera viscosa Lam. is herb distributed in hill slopes of southern peninsular, India. The macerate of the crushed whole plant is used as rectal application, twice a week for one week, to stop diarrhea (Kusamba 2001). The purpose of this research was to study the effect of various concentrations of growth hormones on multiple shoot induction and callus development.

*Corresponding author E-mail: saran_gan@rediffmail.com 


\section{Materials and Methods}

Indigofera viscosa was collected from Wolf Hills, Sivanthipatti, Tirunelveli and grown in the greenhouse at Department of Botany, St. Xavier's College, Palayamkottai, Tamil Nadu, India. Nodal and shoot tip explants were collected from healthy plants and used for the present study. The explants were washed in running tap water for 30 minutes. Then they were washed in an agitated solution of liquid detergent $2 \%$ (w/v) (Teepol) for two minutes and rinsed in distilled water three times. Surface sterilization was performed by immersion of the explants in $70 \%$ (w/v) aqueous ethanol for 40 seconds followed by $0.1 \%$ (w/v) mercuric chloride for five minutes. Finally, the materials were thoroughly rinsed with sterile distilled water five times to remove the traces of mercuric chloride. All the explants were cut into pieces approximately 10-15 mm long for inoculation.

Shoot tip and nodal segments $(0.5 \mathrm{~cm})$ of the twigs were cut and cultured on to $8 \%(\mathrm{w} / \mathrm{v})$ agar gelled MS medium supplemented with various growth regulators (NAA, IAA, IBA, BAP and $\mathrm{Kn}$ ) at different concentrations and combinations. Sub-culturing was done at 14 - 21-day intervals. Shoot buds were further cultured for elongation in the same medium for two-times at 7-day intervals. Elongated shoot buds were rooted on half strength MS medium fortified with different concentrations of auxins (NAA and IBA) alone. The $\mathrm{pH}$ of the medium was adjusted to 5.8 before autoclaving. All cultures were incubated at $25 \pm 2^{\circ} \mathrm{C}$ under $16 / 8 \mathrm{~h}$ photoperiods. After 12 weeks, plantlets with roots were successfully planted in pot soil through gradual acclimatization.

\section{Results and Discussion}

Multiple shoot formation

The present investigation was carried out to explore the morphogenic potential of Indigofera viscosa by using different combinations of growth regulators. The nodal explants resumed new bud growth by proliferating the axillary shoot within 1-2 weeks of culture. Nodal segments inoculated on MS medium fortified with $\mathrm{Kn}$ and NAA for the proliferation of axillary bud. Proliferation of axillary bud was observed on MS medium having Kn (1 mg $\left.\mathrm{L}^{-1}\right)$ and NAA $\left(0.5 \mathrm{mg} \mathrm{L}^{-1}\right)$ but these proliferated axillary buds remained undifferentiated till one month. However, axillary buds proliferated on NAA $\left(1.5 \mathrm{mg} \mathrm{L}^{-1}\right)$ and BAP $\left(1.0 \mathrm{mg} \mathrm{L}^{-1}\right)$ underwent multiplication of shoots (Fig.a). A notable frequency of shoot formation from node explants was observed $(69.42 \%)$ on regeneration medium with NAA $\left(2.5 \mathrm{mg} \mathrm{L}^{-1}\right)$ and BAP $\left(2.0 \mathrm{mg} \mathrm{L}^{-1}\right)$ (Fig. b). Some of these shoots were rooted on the same medium (Fig.c, d). Within 4 weeks of inoculation, axillary meristem elongated up to $3.5-4 \mathrm{~cm}$ in height. NAA and BAP combination proved to be the most effective treatment for promoting shoot multiplication (3-5 shoots/explant, each shoot having 3 to 4 nodes) within four weeks of subculture (Table 1). Similar results were reported in legume trees Acacia mearnsii and Albizia odoratissima (Beck et al. 2001, Rajeshwari and Paliwal 2008). Contrary to the present results, modified MS medium along with BAP (1.5 $\mathrm{mg} / \mathrm{l})$ and BAP $(1 \mathrm{mg} / \mathrm{l})$ in MS medium also stimulated the multiplication of shoots in Acacia nilotica and $A$. senegal respectively (Dewan et al. 1992, Khalafalla and Daffalla 2008). 
In vitro studies on Indigofera viscosa Lam.

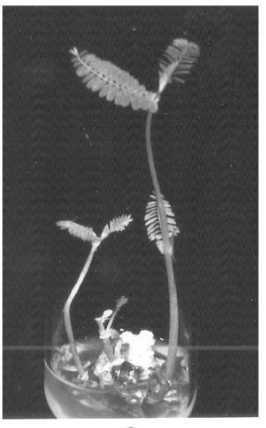

a

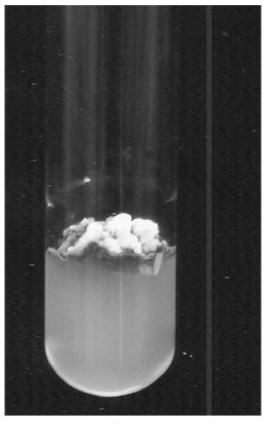

e

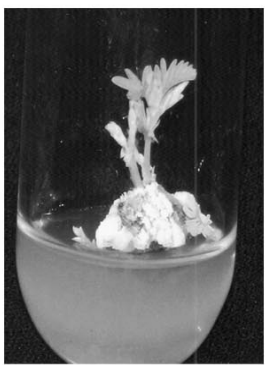

h

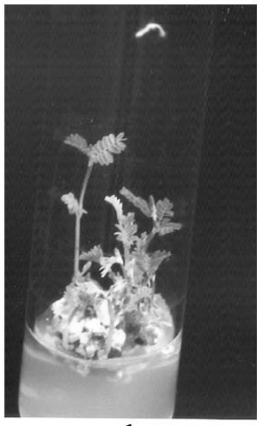

b

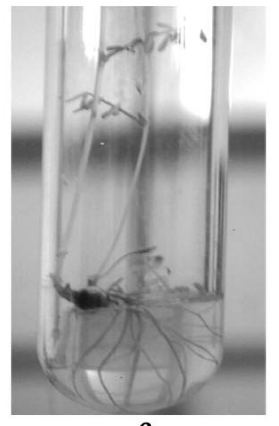

C

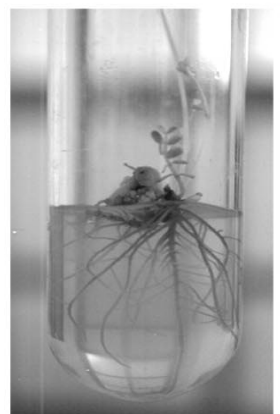

d

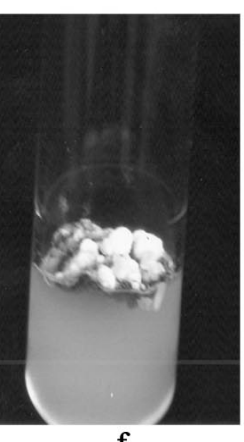

f

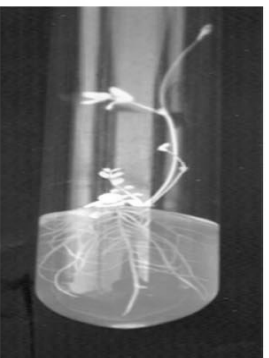

i

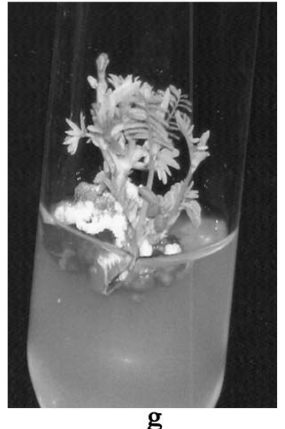

g

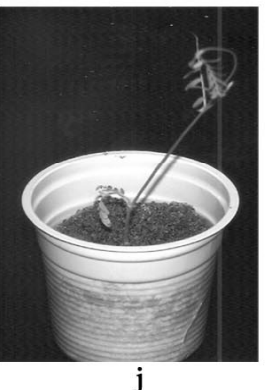

a. Induction of multiple shoots on MS medium containing NAA (1.5 $\left.\mathrm{mg} \mathrm{L}^{-1}\right)$ and BAP (1.0 $\left.\mathrm{mg} \mathrm{L}^{-1}\right)$ from nodal explant

b. Induction of multiple shoots on MS medium containing NAA $\left(2.5 \mathrm{mg} \mathrm{L}^{-1}\right)$ and BAP $\left(2.0 \mathrm{mg} \mathrm{L}^{-1}\right)$ from nodal explant after 20 days of culture.

c.\&d. Elongation and rooting of adventitious shoots in culture medium with BAP and NAA without intervening callus

e. Callus formation on MS medium supplemented with $1.5 \mathrm{mg} \mathrm{L}^{-1} 2,4-\mathrm{D}$ after 10 days of culture.

e. Callus formation on MS medium supplemented with $1.5 \mathrm{mg} \mathrm{L}^{-1} 2,4-\mathrm{D}$ after 10 days of culture.
f. Callus formation on MS medium supplemented with $0.5 \mathrm{mg} \mathrm{L}^{-1} 2,4-\mathrm{D}$ after 12 days of culture.

g. \& h.Multiple shoot tip along with the callus at the base on MS medium supplemented with BAP and IAA

Microshoot rooted on MS medium supplemented with $0.2 \mathrm{mg} \mathrm{L}^{-1}$ IBA showing well developed root system from callus.

j. Hardened plant in polycup containing sterile soil and vermiculate

Fig. $\mathrm{a}-\mathrm{j}$. 
Table 1. Effect of different concentrations and combinations of growth regulators in MS medium on direct proliferation of shoot from nodal and shoot tip explants of $I$. viscosa.

\begin{tabular}{|c|c|c|c|c|c|c|c|c|c|}
\hline \multirow{2}{*}{$\begin{array}{l}\text { NAA } \\
m g L^{-1}\end{array}$} & \multirow{2}{*}{$\begin{array}{c}\text { KIN } \\
m g ~ L-1\end{array}$} & \multirow{2}{*}{$\begin{array}{l}\text { BAP } \\
m g L^{-1}\end{array}$} & \multirow{2}{*}{$\begin{array}{l}\text { No. of } \\
\text { explants } \\
\text { used }\end{array}$} & \multicolumn{3}{|c|}{ Nodal explants } & \multicolumn{3}{|c|}{ Shoot tip explants } \\
\hline & & & & $\begin{array}{c}\% \text { of } \\
\text { regenerated } \\
\text { shoots }\end{array}$ & $\begin{array}{c}\text { Mean } \\
\text { number } \\
\text { of shoot } \\
\text { explants }\end{array}$ & $\begin{array}{l}\text { Mean } \\
\text { length of } \\
\text { shoot } \\
\text { (in } \mathrm{cm} \text { ) }\end{array}$ & $\begin{array}{c}\% \text { of } \\
\text { regenerated } \\
\text { shoots }\end{array}$ & $\begin{array}{c}\text { Mean } \\
\text { number of } \\
\text { shoot } \\
\text { explants }\end{array}$ & $\begin{array}{l}\text { Mean } \\
\text { length } \\
\text { of shoot } \\
\text { (in cm) }\end{array}$ \\
\hline 0 & 0.5 & 0 & 20 & - & - & - & - & - & - \\
\hline 0.5 & 1.0 & 0 & 20 & 45 & $5.0 \pm 0.2$ & $11.1 \pm$ & 60 & $3.2 \pm 0.3$ & $4.4 \pm$ \\
\hline 1.0 & 1.5 & 0 & 20 & 50 & $5.3 \pm 0.2$ & 0.4 & 45 & $3.8 \pm 0.3$ & 0.2 \\
\hline 1.5 & 2.0 & 0 & 20 & 65 & $6.2 \pm 0.1$ & $14.2 \pm$ & 50 & $3.3 \pm 0.5$ & $3.6 \pm$ \\
\hline 2.0 & 2.5 & 0 & 20 & 55 & $5.1 \pm 0.6$ & 0.2 & 35 & $1.8 \pm 0.2$ & 0.5 \\
\hline 2.5 & 3.0 & 0 & 20 & 60 & $2.5 \pm 0.2$ & $\begin{array}{c}15.4 \pm \\
0.1 \\
7.6 \pm 0.5 \\
3.8 \pm 0.4\end{array}$ & 15 & $1.6 \pm 0.3$ & $\begin{array}{c}3.4 \pm \\
0.3 \\
3.1 \pm \\
0.5 \\
2.8 \pm \\
0.4\end{array}$ \\
\hline 0.5 & 0 & 0 & 20 & - & - & - & - & - & - \\
\hline 1.0 & 0 & 0.5 & 20 & 60 & $4.3 \pm 0.1$ & $8.1 \pm 0.2$ & 35 & $4.74 \pm 0.3$ & $3.7 \pm$ \\
\hline 1.5 & 0 & 1.0 & 20 & 70 & $5.2 \pm 0.6$ & $11.2 \pm$ & 55 & $2.58 \pm 0.4$ & 0.7 \\
\hline 2.0 & 0 & 1.5 & 20 & 40 & $4.7 \pm 0.1$ & 0.3 & 15 & $3.42 \pm 0.2$ & $4.4 \pm$ \\
\hline 2.5 & 0 & 2.0 & 20 & 70 & $4.2 \pm 0.8$ & $9.6 \pm 0.2$ & 25 & $3.32 \pm 0.3-$ & 0.4 \\
\hline 3.0 & 0 & 2.5 & 20 & 55 & $3.9 \pm 1.1$ & $\begin{array}{l}8.8 \pm 0.1 \\
7.3 \pm 0.3\end{array}$ & - & & $\begin{array}{c}2.7 \pm \\
0.2 \\
3.5 \pm \\
0.2\end{array}$ \\
\hline
\end{tabular}

\section{Callus induction}

Callus induction was recorded on all regeneration media (Table 2). However, the intensity of callus formation increased with the increase of concentration of 2,4-D. Lower concentration of 2, 45-T did not favour the callus induction. Callus was initiated from the node in $10-15$ days. The maximum of $72.4 \%$ callus induction was observed on MS medium supplemented with $1.5 \mathrm{mg} \mathrm{L}^{-1}$ 2,4-D ( Fig. e). 2,4-D supplemented media with $0.5 \mathrm{mg} \mathrm{L}^{-1}$ also showed the best response after 12 day of culture and $61.7 \%$ explants showed callus proliferation in this combination ( Fig. f). Combination of 2,4-D and 2, 4, $5-\mathrm{T}$ is moderately support the growth of callus. All the concentrations of 2,4-D were proved better than 2, 4, 5-T and the results were statistically significant. Generally the callus exhibits white colour and compact.

\section{Shoot regeneration}

Node and shoot tip explants derived calli were cultured on MS medium supplemented with various concentrations and combinations of BAP and IAA (shoot regeneration medium). Calli turned green compact and shoot buds were induced after four weeks of culture (Fig. g, h). All of the explants derived calli were not assorted in shoot bud regeneration. Higher frequency of shoot regeneration was obtained in MS medium supplemented with BAP $\left(0.5 \mathrm{mg} \mathrm{L}^{-1}\right)$ and IAA $\left(0.2 \mathrm{mg} \mathrm{L}^{-1}\right)$ (Table 3). The observation on the synergistic effect of BAP in combination with IAA on promotion of shoot regeneration of this medicinal plant species is in agreement with that of several plant species (Vidya et al. 2005). However, maximum number of shoots was obtained in MS medium fortified with IAA $\left(0.2 \mathrm{mg} \mathrm{L}^{-1}\right)$. The beneficial $(2-4 \mathrm{~cm}$ long) shoot length was observed in all the concentrations and combinations of shoot regeneration media after 8 weeks of culture. 
Table 2. Response of different treatments of 2,4-D and 2, 4,5-T on callus induction on nodal and shoot tip explants in I. viscosa.

\begin{tabular}{|c|c|c|c|c|c|c|c|}
\hline \multicolumn{2}{|c|}{$\begin{array}{l}\text { Plant growth } \\
\text { regulators } \mathrm{mg} \mathrm{L}^{-1}\end{array}$} & \multirow{2}{*}{$\begin{array}{c}\text { Number } \\
\text { of } \\
\text { explants }\end{array}$} & \multirow[t]{2}{*}{$\begin{array}{c}\text { Days to } \\
\text { initiate callus }\end{array}$} & \multicolumn{2}{|r|}{$\begin{array}{c}\text { Nodal } \\
\text { explants }\end{array}$} & \multicolumn{2}{|c|}{$\begin{array}{l}\text { Shoot tip } \\
\text { explants }\end{array}$} \\
\hline $2,4-D$ & $\begin{array}{l}2,4,5- \\
T\end{array}$ & & & $\begin{array}{c}\% \text { of } \\
\text { success }\end{array}$ & $\begin{array}{c}\text { Nature of } \\
\text { callus }\end{array}$ & $\begin{array}{c}\% \text { of } \\
\text { success }\end{array}$ & $\begin{array}{l}\text { Nature } \\
\text { of callus }\end{array}$ \\
\hline 0.5 & - & 25 & $10-15$ days & 60 & White \& compact & 12 & White \& compact \\
\hline 1.0 & - & 25 & $10-15$ days & 56 & White \& compact & 20 & White \& compact \\
\hline 1.5 & - & 25 & $10-15$ days & 72 & White \& compact & 24 & White \& compact \\
\hline 2.5 & - & 25 & $10-15$ days & 60 & Pale compact & - & - \\
\hline 3.0 & - & 25 & - & - & - & - & - \\
\hline- & 0.5 & 25 & - & - & - & - & - \\
\hline- & 1.0 & 25 & $10-15$ days & 24 & White \& compact & 32 & White \& compact \\
\hline- & 1.5 & 25 & $10-15$ days & 20 & White \& compact & 44 & White \& compact \\
\hline- & 2.5 & 25 & $10-15$ days & 48 & White \& compact & 48 & Pale Green \\
\hline- & 3.0 & 25 & $10-15$ days & 40 & White \& compact & - & - \\
\hline 0.5 & 0.5 & 25 & $10-15$ days & 44 & Pale green & 28 & Pale compact \\
\hline 1.0 & 0.5 & 25 & $10-15$ days & 56 & Pale greenish yellow & 36 & White \& compact \\
\hline 1.5 & 0.5 & 25 & $10-15$ days & 32 & Pale compact & 40 & Pale green \\
\hline 2.5 & 0.5 & 25 & - & - & - & & \\
\hline
\end{tabular}

Table 3. Shoot organogenesis from initiated callus on nodal and shoot tip explants in I. viscosa.

\begin{tabular}{|c|c|c|c|c|c|c|}
\hline \multirow{2}{*}{$\begin{array}{c}\text { Treatment } \\
\mathrm{mg} \mathrm{L}^{-1}\end{array}$} & \multirow{2}{*}{$\begin{array}{l}\text { Days to } \\
\text { initiate } \\
\text { shoots }\end{array}$} & \multirow{2}{*}{$\begin{array}{l}\text { Number of } \\
\text { explants }\end{array}$} & \multicolumn{2}{|c|}{ Node } & \multicolumn{2}{|c|}{ Shoot tip } \\
\hline & & & $\begin{array}{c}\% \text { of } \\
\text { success }\end{array}$ & $\begin{array}{c}\text { Mean No. of } \\
\text { multiple } \\
\text { shoots }\end{array}$ & $\begin{array}{c}\% \text { of } \\
\text { success }\end{array}$ & $\begin{array}{c}\text { Mean No. of } \\
\text { multiple } \\
\text { shoots }\end{array}$ \\
\hline $\mathrm{MS}+\mathrm{BAP} 0.2$ & $15-20$ & 25 & 12 & 2.2 & 12 & 1.4 \\
\hline $\mathrm{MS}+\mathrm{BAP} 0.5$ & $15-20$ & 25 & 12 & 2.3 & 20 & 2.2 \\
\hline $\mathrm{MS}+\mathrm{IAA} 0.2$ & $15-20$ & 25 & 32 & 3.9 & 20 & 2.5 \\
\hline MS + IAA 0.5 & $15-20$ & 25 & 44 & 2.1 & 32 & 3.4 \\
\hline $\mathrm{MS}+\mathrm{BAP} 0.5+$ IAA 0.2 & $15-20$ & 25 & 72 & 3.1 & 36 & 3.0 \\
\hline
\end{tabular}

\section{Rooting of regenerated shoots}

Elongated shoots were excised from regeneration medium and then transferred to MS medium supplemented with $0.2-1.0 \mathrm{mg} \mathrm{L}^{-1}$ IBA or NAA (Table 4). However, IBA was found to be the best rooting hormone than IAA or NAA. Similar results are well documented (Rehman et al. 2003). Higher frequency (81.2\%) of root induction was obtained in MS medium supplemented with $0.2 \mathrm{mg} \mathrm{L}^{-1} \mathrm{IBA}$ (Plate: i). The maximum number of roots was observed in $0.6 \mathrm{mg}$ 
$\mathrm{L}^{-1} \mathrm{IBA}$. However, the root length was varied in each treatment. MS medium supplemented with IBA $\left(0.8 \mathrm{mg} \mathrm{L}^{-1}\right)$ was produced thick and hair-like secondary roots.

Table 4. Effect of growth hormones on average rooting of in-vitro developing shoots of $I$. viscosa.

\begin{tabular}{|c|c|c|c|c|}
\hline \multicolumn{2}{|c|}{$\begin{array}{l}\text { Plant growth } \\
\text { regulators } \mathrm{mg} \mathrm{L}^{-1}\end{array}$} & $\begin{array}{l}\% \text { of } \\
\text { rooting }\end{array}$ & $\begin{array}{l}\text { No. of roots } \\
\text { per shoots }\end{array}$ & $\begin{array}{c}\text { Average } \\
\text { root length }(\mathrm{cm})\end{array}$ \\
\hline \multirow[t]{5}{*}{ IBA } & 0.2 & $81.2 \pm 2.6$ & $3.6 \pm 0.1$ & $3.4 \pm 0.6$ \\
\hline & 0.4 & $47.2 \pm 2.2$ & $4.4 \pm 0.1$ & $6.4 \pm 0.71$ \\
\hline & 0.6 & $35.8 \pm 2.6$ & $5.2 \pm 0.6$ & $8.2 \pm 0.6$ \\
\hline & 0.8 & $46.5 \pm 1.1$ & $2.1 \pm 0.4$ & $9.1 \pm 0.2$ \\
\hline & 1.0 & 32. $3 \pm 1.4$ & $1.5 \pm 1.5$ & $5.5 \pm 0.3$ \\
\hline \multirow[t]{5}{*}{ NAA } & 0.2 & $18.62 \pm 1.5$ & $3.0 \pm 0.3$ & $2.4 \pm 0.3$ \\
\hline & 0.4 & $22.2 \pm 2.6$ & $4.9 \pm 0.1$ & $4.9 \pm 0.1$ \\
\hline & 0.6 & $43.2 \pm 1.7$ & $3.2 \pm 0.2$ & $5.2 \pm 0.2$ \\
\hline & 0.8 & $25.8 \pm 0.6$ & $3.6 \pm 0.1$ & $3.6 \pm 0.1$ \\
\hline & 1.0 & - & - & - \\
\hline
\end{tabular}

- $\quad$ Values are the mean of three replicates with 15 explants.

\section{Acclimatization and establishment in soil}

The rooted plantlets were carefully taken from the culture tubes and then washed with tap water and followed by sterile water. After washing, the rooted plantlets were successfully transferred to poly cups containing sterile soil and vermiculate (1:1). The acclimatized plantlets were successfully established in the field with $70 \%$ survivability (Fig. j).

\section{References}

Bakasso S A, Lamien-Meda C E, Lamien M, Kiendrebeogo J, Millogo A G, Ouedraogo Nacoulma O G. 2008. Polyphenol contents and antioxidant activities of five Indigofera species (Fabaceae) from Burkina Faso, Pak. J Biol Sci 11, 1429-1435. http://dx.doi.org/10.3923/pjbs.2008.1429.1435, PMid: 18817242

Beck S L, Dunlop R, Staden J V .2001. Meristem culture of Acacia mearnsii, Plant Growth Regulation 3, 49-58.

Dewan A, Nanda K, Gupta SC. 1992. In-vitro micropropagation of Acacia nilotica subsp, indica Brenan via cotyledonary nodes, Plant Cell Report 12, 18-21. http://dx.doi.org/10.1007/BF00232415,PMid:24201723

Polhill R M, Raven P H Stirton C H. 1981. Evolution and systematics of the Leguminosae, In: Advances in legume systematics edited by RM Polhill \& PH Raven, Part 1, (Royal Botanic Gardens, Kew), 425.

Judd W S, Campbell C S, Kellogg E A, Stevens P F.1999. Plant Systematics: a phylogenetic approach. (Sinauer Associates, Sunderland p. 464.

Kusamba Chifundera. 2001. Contribution to the inventory of medicinal plants from the Bushi area South Kivu Province Democratic Republic of Congo, Fitoterapia 72, 351-368. http://dx.doi.org/10.1016/S0367-326X(00)00294-X

Rajeshwari V, Paliwal K. 2008. In-vitro adventitious shoot organogenesis and plant regeneration from seedling explants of Albizia odoratissima L.f. (Benth.) In-vitro cellular and Developmental Biology 44 (2), 78-83. http://dx.doi.org/10.1007/s11627-008-9120-7

Khalafalla M M, Daffalla H M. 2008. In-vitro Micropropagation and Micrografting of Gum Arabic Tree, Acacia senegal (L.) Wild. Internationa J Sustainable Crop Production 3(1), 19 -27.

Vidya S M, Krishna V, Manjunatha B K, Shankar Murthy K. 2005. Micropropagation of Entala pursaetha DC. - An endangered medicinal plant of Western Ghats, Indian J Biotech 4, 561 - 564.

Rehman M M, Amin M N, Jahan H S, Ahmed R, 2003. In-vitro regeneration of plantlets of Curcuma longa L. a valuable spice, Asian J Plant Science 3, 306-3. 